\title{
Development of free fluorine and formaldehyde oil and water repellent finishes for cotton fabrics through polymerization of bio-based stearic acid with carboxylic acids
}

DOI: 10.35530/IT.071.02.1731

SHARIF RABIA

AHMAD SYED WAQAS

MOHSIN MUHAMMAD

HAJI GHULAM QUTAB

RAMZAN NAVEED

\section{ABSTRACT - REZUMAT}

Development of free fluorine and formaldehyde oil and water repellent finishes for cotton fabrics through polymerization of bio-based stearic acid with carboxylic acids

This research is an attempt to develop nontoxic and sustainable oil and water repellent which is fluorine and formaldehyde free. For this purpose, stearic acid was polymerized with formaldehyde free cross-linkers, such as maleic acid and acrylic acid. Sodium hypophosphite was used as a catalyst and triethanolamine as an enhancer during the polymerization. Polymerization conditions were optimized such as temperature, time and atmosphere. The prepared recipes were then applied onto the cotton fabrics. The obtained results reveal that the finished cotton fabrics achieves good oil and water repellency, crease resistance, soil resistance, and antimicrobial properties. In addition, the surface of finished cotton fabrics was characterized via SEM, EDX, FTIR, XRD, and TGA.

Keywords: oil and water repellency, maleic acid, acrylic acid, functional textile, eco-friendly.

Dezvoltarea de finisări oleofobe și hidrofobe fără fluor și formaldehidă prin polimerizarea acidului stearic bio cu acizi carboxilici pentru țesături din bumbac

Acest studiu este o încercare de obținere a finisărilor hidrofobe și oleofobe non-toxice și durabile, care nu conțin fluor și formaldehidă. În acest scop, acidul stearic a fost polimerizat cu agenţi de reticulare fără formaldehidă, precum acid maleic și acid acrilic. Hipofosfitul de sodiu a fost utilizat în calitate de catalizator, iar trietanolamina ca agent de intensificare în timpul polimerizării. Condițiile de polimerizare au fost optimizate, din punctul de vedere al temperaturii, duratei și atmosferei. Rețetele preparate au fost apoi aplicate pe țesături din bumbac. Rezultatele au arătat faptul că țesăturile din bumbac finisate sunt hidrofobe și oleofobe, prezintă rezistență la șifonare, rezistență la murdărie și proprietăți antimicrobiene. În plus, suprafețele țesăturilor din bumbac finisate au fost caracterizate utilizând SEM, EDX, FTIR, XRD și TGA.

Cuvinte-cheie: hidrofob și oleofob, acid maleic, acid acrilic, material textil funcțional, ecologic

\section{INTRODUCTION}

Cotton is one of the most abundantly available fibrous biomass materials and has been extensively used in many textile areas, as it exhibits various attractive properties [1] such as hydrophilicity, wearing comfort, breathability [2] and good mechanical strength [3]. However, it lacks oil and water repellency. To meet the demand of customers several chemical finishes are available in the market. These chemical finishes can impart function properties to the cotton fabric such as flame retardancy [4-5], ultraviolet protection [6], antibacterial activity [7], corrosion inhibition, crease recovery [8], self-cleaning properties [9], as well as water and oil repellency [10]. In order to make cotton fabric oil and water repellent its surface energy should be lowered by application of chemical finishes such as silicone repellents [11], fluorocarbon-based repellents [12], paraffin repellents [13] and polyurethanes-based repellents [14]. Most of these finishes are either expensive, noxious, nondurable or less efficient.
Among them, fluorocarbon finishes based on C8 chemistry are most attractive as they significantly lower the surface energy of the cotton fabric $(\leq 18$ dynes/cm) to impart excellent oil and water repellency [15]. However, due to their adverse effect on the environment and potential toxic effect on human, there is an urgent need for fluorine-free oil and water repellent alternative. Moreover, C8 based perfluorinated and polyfluorinated chemicals (PFCs) are part of 11 priority chemicals that are banned to use internationally in the textile and leather process industry [16].

Nowadays, emergent research is focused on non-fluorine, eco-friendly oleophobic and hydrophobic finishes. An alternative to fluorinated compounds is long alkyl chain compounds [17]. Use of stearic acid to impart hydrophobicity has been reported in the literature. Stearic acid is an ecological, long-chain fatty acid which is used as a water repellent finish. Despite this, it lacks durability as well as higher concentration is required for effective results. In addition, it only repels water but not oil. Stearic acid is also used to 
impart hydrophobicity to cotton and non-cotton fabric as reported in literature. Cotton fabric can be made more hydrophobic by treating it with titanium dioxide [18], silica nanoparticles [19], and zinc hydroxide [20] followed by dipping in stearic acid solution. However, the washing durability of the coating was not good. Hydrophobicity of non-cotton fabric such as jute fibers [21] and polyester fabric [22], can also be increased by stearic acid modification process. However, the researchers did not present the durability of coating in terms of washing. Hydrophilic behavior of recycled jute fiber treated with $\mathrm{TiO}_{2}$ solutions has been shifted to hydrophobic by immersing it in stearic acid solution. There was also increase in the contact angle of the treated fabric [23]. However, stearic acid is nondurable and exhibit only water repellency.

To enhance the functional properties, durability and performance of cotton, different techniques have been introduced. Crosslinking of cellulose, with certain compounds through a chemical reaction to bridge cellulose chain for effective performance and durability is one of them [24]. Depending on chemical structure, crosslinkers are further classified as formaldehyde-based and formaldehyde-free crosslinkers. Formaldehyde-based crosslinkers dominated in past as they provide outstanding wrinkle resistance at low price but on the other hand, they reduce fabric strength, increases stiffness and release formaldehyde which is a lethal compound for human as it is now declared as confirmed carcinogenic [25]. Therefore, formaldehyde-free cross-linkers like polycarboxylic acids (PCAs) are getting more popular as they can increase washing durability and wrinkle resistance of cotton fabric without involving formaldehyde [26]. The reaction mechanism of crosslinking of PCAs with cotton is carried out in two steps: dehydration of two adjacent carboxyl groups forms cyclic anhydride, and then esterification reaction takes place between cellulose and intermediate anhydride to form ester bond [27-28].

Among all effective PCAs, BTCA is one of the most effective crosslinkers for cotton but it causes considerable damage to mechanical properties of cotton fabric and it is very expensive [29]. Citric acid is a biobased cross-linker and it has been reported to crosslink cotton fabric [30] but its application is inhibited due to its yellowing effect [31]. Therefore, the use of cost-effective polycarboxylic acids such as maleic acid (dicarboxylic acid) [32] and monocarboxylic acid such as acrylic acid has also been reported in the literature [33]. However, carboxylic acid does not impart any oil and water repellency on their own.

Therefore, in this research stearic acid was polymerized with maleic acid and acrylic acid, in the presence of catalyst SHP and triethanolamine TEA under various polymerization conditions, temperature and time. The newly developed finish recipes were applied onto the cotton fabric and treated fabric performance were also assessed.

\section{EXPERIMENTAL SECTION}

Materials

Scoured, bleached and $100 \%$ pure cotton fabric was used without any other finishing processes. Lab grade stearic acid (SA), maleic acid (MA), acrylic acid (AA), sodium hypophosphite monohydrate (SHP), triethanolamine (TEA) and Isopropyl alcohol (IPA) were purchased from Sigma Aldrich. Lab grade distilled water was used as a solvent. All chemicals were used directly without any further purification.

\section{Chemical and fabric preparation}

The polymerization reaction was carried out in a temperature and time-controlled polymerization reactor coupled with a stirrer and vacuum pump. A measured amount of fluorine-free water repellent monomer; stearic acid along with non-toxic and formaldehydefree crosslinker such as maleic acid and acrylic acid in the presence of catalyst SHP and enhancer TEA were fed to the polymerization reactor. Optimization of the operation parameter was carried out. Finally, the reaction was carried out at optimum condition of $160^{\circ} \mathrm{C}$ for 3 hours in vacuum conditions for maleic acid and at $200^{\circ} \mathrm{C}$ for 2 hours for acrylic acid. The obtained recipes were diluted with Isopropyl alcohol and water in two different beakers. The pad-dry-cure method was used to apply finishes onto the fabric. Two roll laboratory padder with $70 \%$ pick up was used to apply the recipe onto the fabric. After that, cotton fabric was dried at $100^{\circ} \mathrm{C}$ for 180 seconds and cured at $180^{\circ} \mathrm{C}$ for 120 seconds. Prior to any testing, conditioning of all test sample was carried out for 24 hours at $20 \pm 5^{\circ} \mathrm{C}$ and $65 \%$ of relative humidity.

\section{Evaluation of fabric properties}

AATCC and ISO test standard methods were used to evaluate the easy-care properties of the treated fabric. For water repellency, AATCC Test Method 193 and AATCC Test Method 22 was used. For oil repellency, AATCC Test Method 118 was employed. To find the crease recovery angle and soil resistance of treated fabric, AATCC Test Method 66-2003 and AATCC Test Method 130 were used respectively. AATCC Test Method 147 was used to investigate the antibacterial properties of the fabric. British Standard BS EN ISO 13934-1 and British Standard BS EN ISO 4674 were used to determining tensile strength and tear strength of coated fabric respectively. To probe air permeability and shrinkage of treated fabric, British Standard BS EN ISO 9237 and AATCC Test Method 135 were performed respectively. The durability of the coating was inspected by washing method IS0 105-C10:2006.

\section{CHARACTERIZATION TO VALIDATE THE RESULTS}

\section{Contact angle}

DSA 30 was used to find wet contact angle (WCA) of modified and un-modified cotton fabric. A camera was attached with a computer interface to capture 
and assess the shape and contact angle of drop placed on the fabric. The contact angle of control fabric and the treated fabric was measured.

\section{FTIR analysis}

FTIR spectroscopy technique was employed to determine the degree of ester crosslinking between cellulose/stearic acid/maleic acid and cellulose/ stearic acid/acrylic acid. FTIR spectrum was recorded with a scan range of $500-2500 \mathrm{~cm}^{-1}$ and a resolution of $4 \mathrm{~cm}^{-1}$.

\section{Thermogravimetric analysis}

Thermogravimetric analysis (TGA) of samples was performed to record the mass loss during heating from $25^{\circ} \mathrm{C}$ to $600^{\circ} \mathrm{C}$ with a heating rate of $10^{\circ} \mathrm{C} / \mathrm{min}$. A NETZSCH TG 209F1 Libra (Germany) evolution analyzer was used. The sample mass of 3-5 mg was placed in an alumina crucible in the presence of air.

\section{X-ray diffraction}

The diffractogram of the samples was recorded using X'Pert Pro diffractometer (Netherland) with $\mathrm{Cu} \mathrm{Ka}$ radiation $(\lambda=0.1540 \mathrm{~nm})$ and a generator was running at $45 \mathrm{kV}$ and $40 \mathrm{~mA}$. One of the most important characteristics of cellulose that contribute to its chemical, physical and mechanical properties is its crystallinity. XRD is an analytical technique that provides information on the molecular structure of the finished fabric by measuring the crystallinity index of the samples. Segal crystallinity index was calculated based on the area of amorphous cellulose peak $A_{A M}$ and the total area of all peaks $A_{\text {TOT }}$ of diffractogram [34].

$$
C / \%=1-A_{A M} / A_{T O T}
$$

\section{SEM analysis}

The morphology of cotton fabric before and after application of polymer onto the fabric was observed by scanning electron microscope.

\section{Energy dispersive spectroscopy (EDX)}

Elemental analysis of treated and untreated cotton fabric was carried out by EDX analysis with beam's energy at $5 \mathrm{keV}$. Contents of carbon, oxygen, and fluorine on the cotton fabric surface were determined by EDX.

\section{RESULTS AND DISCUSSION}

In this research, a long-chain fatty acid, stearic acid is polymerized with crosslinkers such as maleic acid and acrylic acid to impart hydrophilicity and oleophobicity to the cotton fabric. The behavior of stearic acid as oil and water repellent was observed by applying it on the cotton fabric without any polymerization. The solution of stearic acid was made in water and an organic solvent Isopropyl alcohol. Stearic acid was only fairly soluble in water at a higher temperature range from 80 to $90^{\circ} \mathrm{C}$ with zero oil and water repellency rating. However, water repellency rating of "2" was achieved when $15 \%$ of stearic acid was dissolved in Isopropyl alcohol, as shown in table 1. The

Table 1

WATER AND OIL REPELLENCY RATING OF THE COTTON FABRIC TREATED WITH STEARIC ACID AND CROSSLINKERS WITHOUT POLYMERIZATION

\begin{tabular}{|c|c|c|c|c|c|c|c|}
\hline Sample & $\begin{array}{l}\text { Oil and } \\
\text { water } \\
\text { repellent }\end{array}$ & Cross-linker & $\begin{array}{c}\text { Catalyst } \\
\text { (SHP) }\end{array}$ & $\begin{array}{l}\text { Enhancer } \\
\text { (TEA) }\end{array}$ & Solvent & $\begin{array}{l}\text { Water } \\
\text { repellency } \\
\text { rating }\end{array}$ & $\begin{array}{l}\text { Oil repellency } \\
\text { rating }\end{array}$ \\
\hline $\begin{array}{c}\text { Recipe A1 } \\
\text { (Control fabric) }\end{array}$ & - & - & - & - & - & w & w \\
\hline A2 (Nuva-3585) & $3 \%$ & - & - & - & $\mathrm{H}_{2} \mathrm{O}$ & 8 & 5 \\
\hline $\mathrm{A} 3$ & $1 \% \mathrm{SA}$ & - & - & - & $\mathrm{H}_{2} \mathrm{O}$ & $w$ & w \\
\hline A4 & $3 \%$ SA & - & - & - & $\mathrm{H}_{2} \mathrm{O}$ & $w$ & w \\
\hline A5 & $5 \%$ SA & - & - & - & $\mathrm{H}_{2} \mathrm{O}$ & $w$ & w \\
\hline A6 & - & $3 \% \mathrm{MA}$ & - & - & $\mathrm{H}_{2} \mathrm{O}$ & $w$ & w \\
\hline A7 & - & $3 \% \mathrm{MA}$ & - & - & IPA & w & w \\
\hline A8 & - & $3 \% \mathrm{AA}$ & - & - & $\mathrm{H}_{2} \mathrm{O}$ & w & w \\
\hline A9 & - & $3 \% \mathrm{AA}$ & - & - & IPA & w & w \\
\hline A10 & - & - & - & $3 \%$ & $\mathrm{H}_{2} \mathrm{O}$ & w & w \\
\hline A11 & $1 \% \mathrm{SA}$ & - & - & - & IPA & 2 & w \\
\hline A12 & $3 \%$ SA & - & - & - & IPA & 2 & w \\
\hline $\mathrm{A} 13$ & $5 \%$ SA & - & - & - & IPA & 2 & w \\
\hline A14 & $15 \% \mathrm{SA}$ & - & - & - & IPA & 2 & w \\
\hline A15 & $25 \%$ SA & - & - & - & IPA & 3 & w \\
\hline A16 & $30 \%$ SA & - & - & - & IPA & 3 & w \\
\hline $\mathrm{A} 17$ & $3 \%$ SA & $5 \% \mathrm{MA}$ & $5 \%$ & $5 \%$ & IPA & 2 & w \\
\hline A18 & $3 \% \mathrm{SA}$ & $5 \% \mathrm{AA}$ & $5 \%$ & $5 \%$ & IPA & 2 & $w$ \\
\hline
\end{tabular}


increased concentration of stearic acid to $25 \%$ results in a higher rating of " 3 " for water repellency. Further increase in the concentration of stearic acid does not affect water repellency rating. The solution of maleic acid and acrylic acid in water and Isopropyl alcohol showed zero oil and water repellency rating. It clearly indicates that carboxylic acid on their own cannot impart any oil and water repellency.

Effect of operational parameters on oil and water repellency rating

Effect of the selection of monomers on water and oil repellency rating

Combination of stearic acid with crosslinker maleic acid or acrylic acid in the presence of catalyst SHP and enhancer TEA under vacuum conditions exhibit water repellency rating of 4 and 3 respectively as shown in table 2. Monomers were selected by performing number of experiments in vacuum condition. Results related to dosage of stearic acid, polymerization time and temperature are described in the figures 1-3.

Vacuum condition exhibited superior results as compared to atmospheric conditions due to lesser side reactions and by-products as shown in table 3 . There is an improvement of one rating of water repellency when polymerization was carried out between stearic acid and either maleic acid or acrylic acid under vacuum and non-vacuum conditions.

\section{Effect of dosage of stearic acid on water and oil repellency rating}

The concentration of stearic acid has a vital effect on water and oil repellency rating. At different concentrations of stearic acid; $11 \%, 16 \%, 25 \%$, and $50 \%$, experiments were performed to find out the optimum value. Figure 1 clearly depicted that with an increase in dosage of stearic acid up to $25 \%$, water and oil repellency rating was also increased for maleic acid for both solvents; water and Isopropyl alcohol. However, at very higher concentration of $50 \%$, the trend remained straight due to saturation effect. For acrylic acid, the same trend as that of maleic acid had been observed for water repellency rating but it exhibits zero rating for oil repellency for both solvents.

SELECTION OF MONOMERS FOR POLYMER SYNTHESIS UNDER VACUUM AT $160^{\circ} \mathrm{C}$ AND THEIR EFFECT ON OIL AND WATER REPELLENCY RATING OF COTTON FABRIC

\begin{tabular}{|c|c|c|c|c|c|c|c|c|}
\hline Sample & $\begin{array}{c}\text { Oil and water } \\
\text { repellent } \\
\text { (SA \%) }\end{array}$ & $\begin{array}{c}\text { Cross- } \\
\text { linker } \\
(\%)\end{array}$ & $\begin{array}{l}\text { Catalyst } \\
\text { (SHP \%) }\end{array}$ & $\begin{array}{c}\text { Enhancer } \\
\text { (TEA \%) }\end{array}$ & Solvent & $\begin{array}{c}\text { Polymerization } \\
\text { temperature } \\
\left({ }^{\circ} \mathrm{C}\right)\end{array}$ & $\begin{array}{c}\text { Water } \\
\text { repellency } \\
\text { rating }\end{array}$ & $\begin{array}{l}\text { Oil repellency } \\
\text { rating }\end{array}$ \\
\hline B1 & 25 & - & - & 5 & IPA & 160 & 3 & w \\
\hline B2 & 25 & $5 \% \mathrm{MA}$ & 5 & - & IPA & 160 & 3 & w \\
\hline B3 & 25 & $5 \% \mathrm{MA}$ & 5 & - & IPA- $\mathrm{H}_{2} \mathrm{O}$ & 160 & 3 & w \\
\hline B4 & 25 & $5 \% \mathrm{MA}$ & - & 5 & IPA & 160 & 2 & w \\
\hline B5 & 25 & $5 \% \mathrm{MA}$ & - & 5 & IPA- $\mathrm{H}_{2} \mathrm{O}$ & 160 & 2 & w \\
\hline B6 & 25 & $5 \% \mathrm{MA}$ & 5 & 5 & IPA & 160 & 4 & 1 \\
\hline B7 & 25 & $5 \% \mathrm{MA}$ & 5 & 5 & $\mathrm{IPA}-\mathrm{H}_{2} \mathrm{O}$ & 160 & 4 & 1 \\
\hline B8 & 25 & $5 \%$ AA & 5 & 5 & IPA & 160 & 3 & w \\
\hline B9 & 25 & $5 \%$ AA & 5 & 5 & IPA- $\mathrm{H}_{2} \mathrm{O}$ & 160 & 3 & w \\
\hline
\end{tabular}

\begin{tabular}{|c|c|c|c|c|c|c|c|c|}
\hline \multicolumn{9}{|c|}{$\begin{array}{l}\text { COMPARISON OF OIL AND WATER REPELLENCY RATING OF THE FINISHED COTTON FABRIC } \\
\text { IN ATMOSPHERIC AND VACUUM POLYMERIZATION AT } 160^{\circ} \mathrm{C}\end{array}$} \\
\hline Sample & $\begin{array}{l}\text { Oil and water } \\
\text { repellent } \\
\text { (SA \%) }\end{array}$ & $\begin{array}{c}\text { Cross- } \\
\text { linker } \\
(\%)\end{array}$ & $\begin{array}{l}\text { Catalyst } \\
\text { (SHP \%) }\end{array}$ & $\begin{array}{l}\text { Enhancer } \\
\text { (TEA \%) }\end{array}$ & Solvent & $\begin{array}{c}\text { Polymerization } \\
\text { temperature } \\
\left({ }^{\circ} \mathrm{C}\right)\end{array}$ & $\begin{array}{l}\text { Water } \\
\text { repellency } \\
\text { rating }\end{array}$ & $\begin{array}{l}\text { Oil repellency } \\
\text { rating }\end{array}$ \\
\hline C1 (atm) & 25 & $5 \% \mathrm{MA}$ & 5 & 5 & IPA & 160 & 3 & w \\
\hline C2 (atm) & 25 & $5 \% \mathrm{MA}$ & 5 & 5 & IPA- $\mathrm{H}_{2} \mathrm{O}$ & 160 & 3 & $w$ \\
\hline C3 (vac) & 25 & $5 \% \mathrm{MA}$ & 5 & 5 & IPA & 160 & 4 & 1 \\
\hline C4 (vac) & 25 & $5 \% \mathrm{MA}$ & 5 & 5 & $\mathrm{IPA}-\mathrm{H}_{2} \mathrm{O}$ & 160 & 4 & 1 \\
\hline C5 (atm) & 25 & $5 \% \mathrm{AA}$ & 5 & 5 & IPA & 160 & 2 & w \\
\hline C6 (atm) & 25 & $5 \% \mathrm{AA}$ & 5 & 5 & IPA- $\mathrm{H}_{2} \mathrm{O}$ & 160 & 2 & $w$ \\
\hline C7 (vacc) & 25 & $5 \%$ AA & 5 & 5 & IPA & 160 & 3 & w \\
\hline C8 (vacc) & 25 & $5 \% \mathrm{AA}$ & 5 & 5 & IPA- $\mathrm{H}_{2} \mathrm{O}$ & 160 & 3 & $w$ \\
\hline
\end{tabular}




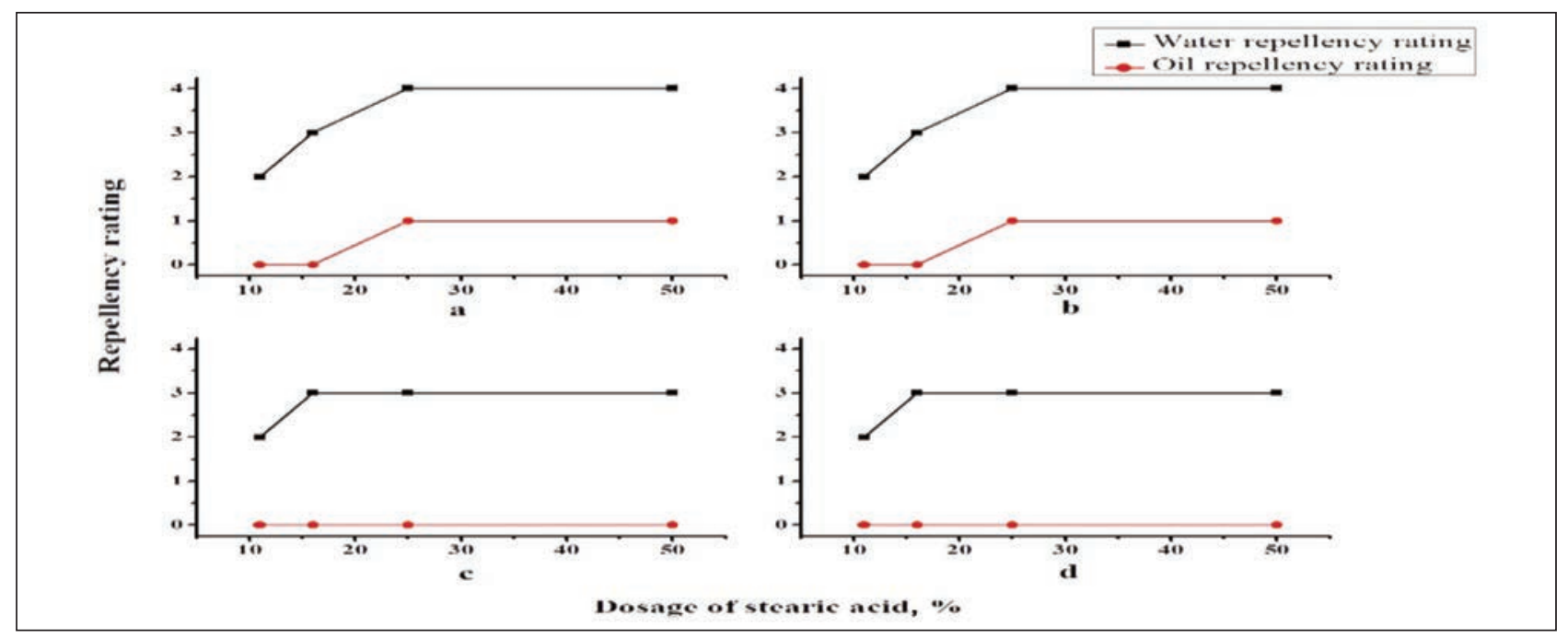

Fig. 1. Optimum dosage of stearic acid at $160^{\circ} \mathrm{C}$ with: $a-$ Maleic acid + IPA; $b-$ Maleic acid + IPA $+\mathrm{H}_{2} \mathrm{O} ; c-\mathrm{Acrylic}$ acid + IPA; $d$ - Acrylic acid + IPA + $\mathrm{H}_{2} \mathrm{O}$

\section{Effect of temperature on water and oil repellency rating}

Figure 2 reflects the influence of temperature on the oil and water repellency rating. It exhibits that as the temperature of reaction raised, water and oil repellency rating increased firstly and then decreased. At lower temperature range, crosslinking efficiency of monomers were low. Literature reports that carboxylic acid esterification reaction starts around $150^{\circ} \mathrm{C}$ and it was also reported that greater the temperature better will be the esterification. In our experimentation we also observed that after $150^{\circ} \mathrm{C}$ repellency rating was improved. The optimum value was observed at a temperature of $160^{\circ} \mathrm{C}$ for a combination of stearic acid and maleic acid and $200^{\circ} \mathrm{C}$ for a combination of stearic acid and acrylic acid.

It is important to note that at the temperature of $100^{\circ} \mathrm{C}$, very less amount of solid melted and it was difficult to apply recipe onto the fabric. As the polymerization temperature further increased after $200^{\circ} \mathrm{C}$, a viscous liquid was formed that makes the fabric very sticky thus decreasing the repellency rating. After the further increase in temperature above $200^{\circ} \mathrm{C}$ up to $450^{\circ} \mathrm{C}$, excessive evaporation started and due to this, the polymerization reactor pressure was also increased and resulted in decreased oil and water repellency rating.

\section{Effect of time on water and oil repellency rating}

Figure 3 exhibited that water and oil repellency rating was first increased and then curve remained constant as the reaction time increased. At the initial stage of the polymerization reaction, more crosslinking occurred between monomers and conversion ratio of monomers to polymer continued to increase. So, water and oil repellency rating increased with the increase of time. The optimum time of polymerization reaction was found to be 3 hours for stearic acid and maleic acid while it is 2 hours for stearic acid and acrylic acid. It is mainly due to the fact that rate of reaction between stearic acid and acrylic acid was high due to the presence of a vinyl group. Nevertheless, at a very prolonged time of 5 hours, water and oil repellency rating remained constant.

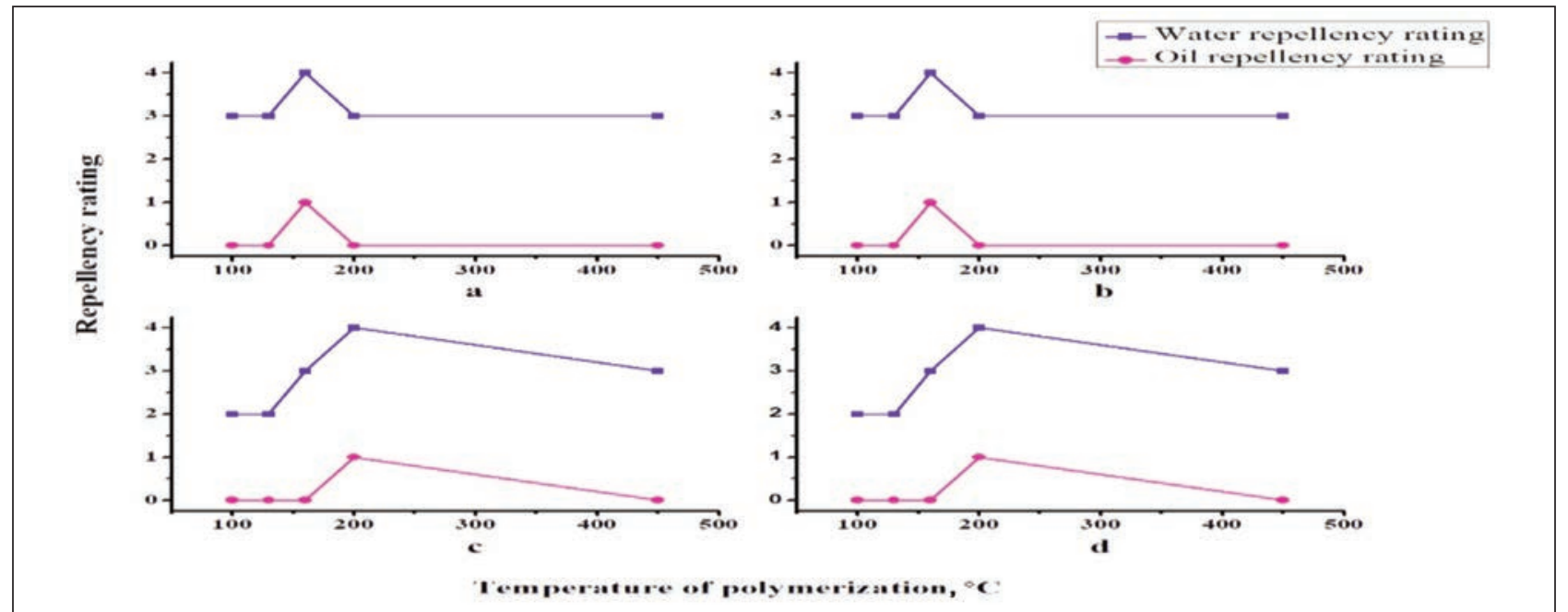

Fig. 2. Optimum temperature for polymerization of stearic acid with: $a-$ Maleic acid + IPA; $b-$ Maleic acid + IPA + $\mathrm{H}_{2} \mathrm{O} ; c-$ Acrylic acid + IPA; $d-$ Acrylic acid + IPA $+\mathrm{H}_{2} \mathrm{O}$ 


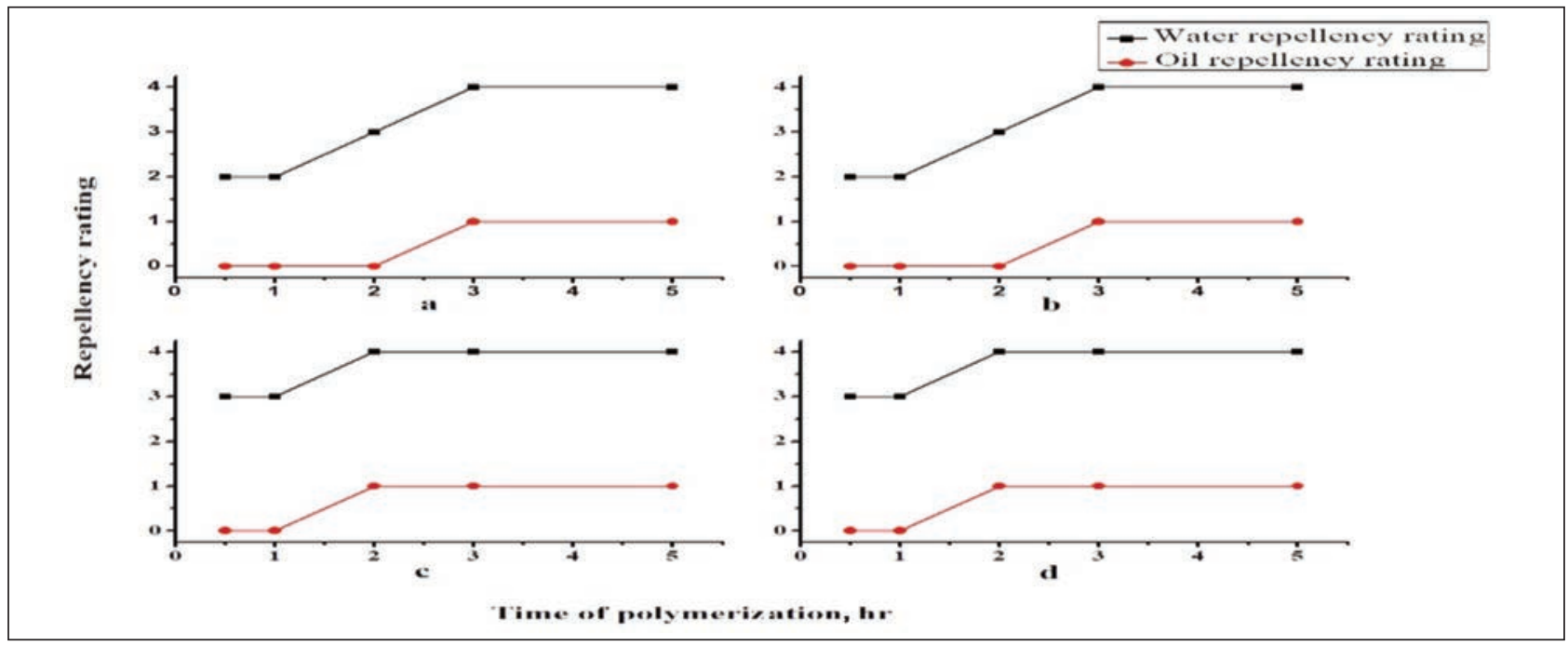

Fig. 3. Optimum time for polymerization of stearic acid with: $a-$ Maleic acid + IPA; $b-$ Maleic acid $+I P A+\mathrm{H}_{2} \mathrm{O}$; $c$ - Acrylic acid + IPA; $d$ - Acrylic acid + IPA + $\mathrm{H}_{2} \mathrm{O}$

\section{Water and oil repellency}

Commercial recipe of Nuva 3585, a C6 based fluorocarbon exhibits water repellency rating of 7 before any wash and it was reduced to 3 after 20 washes for an un-pressed sample. Nevertheless, in case of oil repellency, the fluorocarbon achieved a rating of 2 for the pressed sample after 20 washes. Sample A15, which contain alone stearic acid exhibit water repellency rating of 3 before any wash, but it became wet after 5 washes. Therefore, it can be concluded that stearic acid can only impart water repellency.

\section{Functional properties of the finished fabric}

Use of cotton fabric in various household and industrial application makes the cotton fabric among one of the most widely used fabrics. To assess the diverse application of newly developed recipes, various easy- care and performance properties were evaluated after application of finishes.

Spray test

Spray test was performed to measure the ability of the cotton fabric to repel water. Hydroxyl group present in cellulose are responsible for its water absorbency. After application of the newly developed recipes the spray rating of the treated fabric was improved. Table 4 shows that sample E6, E7, E8, and E9 were rated 70 by comparing with spotted patterns on the standard spray test rating chat. Benchmark sample A2 also rated 70 at rating chart. However, spray test rating for control fabric, sample $A 15, A 7$, and $A 9$ was 0 .

Crease recovery angle (CRA)

Crease recovery of the cotton fabric is one of the most important property which the apparel industry is

FUNCTIONAL PROPERTIES OF FINISHED AND CONTROL COTTON FABRIC AT OPTIMUM TEMPERATURE, THE DOSAGE OF MONOMERS AND TIME UNDER VACUUM CONDITION

\begin{tabular}{|c|c|c|c|c|c|c|c|c|c|}
\hline \multirow{2}{*}{ Sample } & \multirow{2}{*}{$\begin{array}{l}\text { Spray } \\
\text { test } \\
\text { rating }\end{array}$} & \multirow{2}{*}{$\begin{array}{c}\text { Contact } \\
\text { angle } \\
\text { (degree) }\end{array}$} & \multirow{2}{*}{$\begin{array}{l}\text { Air } \\
\text { permeability } \\
\text { retention } \\
(\%)\end{array}$} & \multirow{2}{*}{$\begin{array}{c}\text { Soil } \\
\text { release } \\
\text { rating }\end{array}$} & \multirow{2}{*}{$\begin{array}{c}\text { CRA } \\
(\mathrm{W}+\mathrm{F}) \\
\text { (degree) }\end{array}$} & \multicolumn{2}{|c|}{$\begin{array}{l}\text { Shrinkage } \\
(\%)\end{array}$} & \multirow{2}{*}{$\begin{array}{c}\text { Tensile } \\
\text { strength } \\
\text { retention } \\
(\%)\end{array}$} & \multirow{2}{*}{$\begin{array}{c}\text { Tear } \\
\text { strength } \\
\text { retention } \\
(\%)\end{array}$} \\
\hline & & & & & & Warp & Weft & & \\
\hline A1 (Control Fabric) & 0 & 0 & 100 & 1 & 144 & 4 & 3 & 100 & 100 \\
\hline A2 (Nuva-3585) & 70 & 145 & 71 & 3 & 165 & 3 & 2 & 84 & 81 \\
\hline A15 (SA) & 0 & 101 & 76 & 3 & 150 & 3 & 2 & 87 & 94 \\
\hline A7 (MA) & 0 & 0 & 80 & 4 & 191 & 3.2 & 1 & 80 & 75 \\
\hline A9 (AA) & 0 & 0 & 84 & 3 & 185 & 3.7 & 1.8 & 82 & 76 \\
\hline $\begin{array}{l}\text { E6 (SA+MA+ } \\
\text { SHP+TEA+IPA) }\end{array}$ & 70 & 142 & 78 & 4 & 178 & 3.1 & 1.2 & 81 & 75 \\
\hline $\begin{array}{l}\mathrm{E} 7(\mathrm{SA}+\mathrm{MA}+ \\
\left.\mathrm{SHP}+\mathrm{TEA}+\mathrm{IPA}+\mathrm{H}_{2} \mathrm{O}\right)\end{array}$ & 70 & 139 & 77 & 4 & 172 & 3.1 & 1.2 & 79 & 73 \\
\hline $\begin{array}{l}\text { E8 (SA+AA+ } \\
\text { SHP+TEA+ IPA) }\end{array}$ & 70 & 136 & 82 & 4 & 169 & 3.5 & 1.5 & 84 & 81 \\
\hline $\begin{array}{l}\mathrm{E9}((\mathrm{SA}+\mathrm{AA}+\mathrm{SHP}+ \\
\left.\mathrm{TEA}+\mathrm{IPA}+\mathrm{H}_{2} \mathrm{O}\right)\end{array}$ & 70 & 132 & 70 & 4 & 164 & 3.3 & 1.6 & 83 & 78 \\
\hline
\end{tabular}


looking for. Cotton fabric lacks crease resistance due to the amorphous region and weak hydrogen bonding between the chains. The crease recovery behaviour of the cotton fabric can be improved by the formation of a covalent bond with crosslinking agents. Table 4 shows the crease recovery behaviour of the treated and untreated cotton fabric. CRA has a higher value of $191^{\circ}$ and $185^{\circ}$ for maleic acid and acrylic acid respectively due to the esterification reaction between the cotton fabric and carboxylic acids. Maleic acid has higher CRA as it has two carboxylic acid groups as compared to one carboxylic group of acrylic acid. Similarly, recipes E6, E7 E8, and E9 show better crease recovery as compared to untreated cotton fabric. The commercial bench mark sample of A2 exhibited lower CRA as compared to optimized recipes of maleic acid and acrylic acid. It is quite obvious as maleic acid and acrylic acid are cross-linkers, therefore, impart superior crease recovery properties as compared to commercial oil and water repellent recipes.

\section{Air permeability}

Passage of air through cotton fabric is related to another important property which is known as air permeability. It is basically related to the comfort of clothes. The air permeability of the control fabric is set as $100 \%$. As finishes were applied onto cotton fabric, the passage of air through treated fabric decreases to a certain low value as presented in table 4 . The reduced value of air permeability for recipe E6 was $78 \%$ and for recipe E8 it was $82 \%$. However, the commercial recipe of A2 exhibited the least air permeability of $71 \%$.

\section{Soil release}

Table 4 shows that soil release of grade 1 was obtained by control fabric and it has been increased to grade 4 for samples E6, E7, E8 and E9 due to the presence of the carboxylic acid group. Soil release rating of 3 was achieved by using the benchmark commercial recipe of A2. Stearic acid and acrylic acid exhibited the soil release grade of 3 whereas maleic acid has demonstrated a grade of 4 . It is mainly due to the reason that maleic acid has two carboxylic acid groups consequently it can repel the negatively charged soils in a better way.

\section{Strength}

Tensile and tear strength retention of untreated cotton fabric was considered as $100 \%$. Typically, crosslinkers impart loss in strength due to crosslinking at the intermolecular and intramolecular level. Therefore, stress distribution among all molecules is not equal and load withstanding capacity is reduced. Samples treated with maleic acid imparted slightly more reduction in tensile and tear strength retention as compared to maleic acid. It is mainly due to greater cross-linking of maleic acid in comparison with acrylic acid recipes, table 4 .

\section{Shrinkage}

Shrinkage is associated with a change in the dimension of cotton fabric in warp and weft direction after washing. After the application of the newly synthesized finishes, shrinkage test was performed. Cotton fabric treated with acrylic acid exhibit more shrinkage in warp direction having a value of $3.7 \%$ as compared to maleic acid having a value of $3.2 \%$. Again, maleic acid being the better cross-linker will lead to lesser shrinkage as compared to acrylic acid. Sample E6 and $E 7$ both have shrinkage value of $3.1 \%$ in warp direction which was less as compared to the cotton fabric which stands at a value of $4 \%$ in warp direction as shown in table 4. Shrinkage of the commercial recipe $\mathrm{A} 2$ is more than the newly developed recipes.

\section{FTIR analysis}

The strong peaks of carbonyl stretching and ester bond formation between stearic acid, maleic acid and cellulose (E6) as well as stearic acid, acrylic acid with cellulose (E8) appeared at $1703 \mathrm{~cm}^{-1}$ and 1730 and $\mathrm{cm}^{-1}$ respectively as depicted in figure 4 . Whereas the peak at $1156 \mathrm{~cm}^{-1}$ and $1152 \mathrm{~cm}^{-1}$ corresponds to C-O stretching for sample E6 and E8 respectively. These peaks confirmed the ester linkages between recipes and cellulose. However, these ester peaks were not present for control fabric as well as for samples $\mathrm{A} 9$ and $\mathrm{A} 7$.

\section{TGA analysis}

To evaluate the thermal stability of control fabric and treated ones, thermogravimetric analysis (TGA) was performed. Figure 5 shows the TGA curves for control fabric and fabric treated with maleic acid, and fabric treated with acrylic acid respectively. Mass loss of

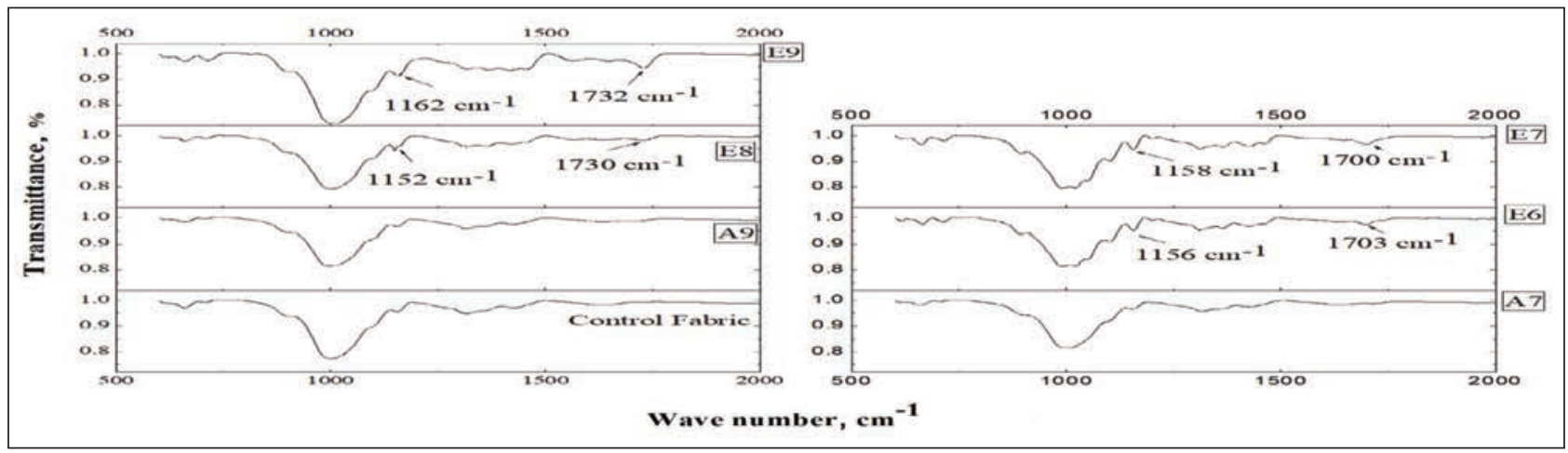

Fig. 4. FTIR spectrum of untreated control fabric and cotton fabric treated with A9, E8, E9, A7, E6, E7 


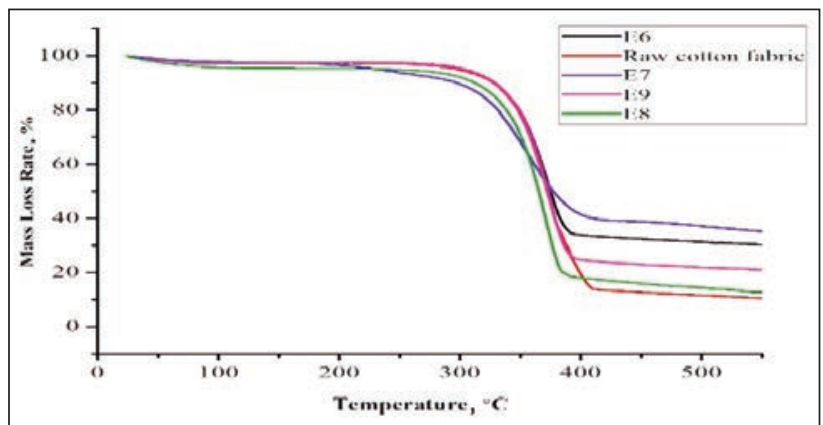

Fig. 5. TGA thermograms for control and modified cotton fabric

thermogram was divided into three regions. In the first region, the dehydration of polymer takes place and the mass loss rate is less than $5 \%$. In the second region, mass loss was due to decomposition caused by pyrolysis and in the last region, there was the conversion of remaining material to carbon residue. The melting point of cellulose is in the range of $260-270^{\circ} \mathrm{C}$. So, in TGA analysis pyrolysis of cotton fabric starts at $265^{\circ} \mathrm{C}$. Maleic acid have the melting point of $135^{\circ} \mathrm{C}$. Therefore, cotton fabric treated with E6, E7, E8 and E9 start decomposing at 261, 219, 262 and 264 respectively.

\section{XRD analysis}

Cellulose showed its diffraction peaks at $2 \theta=15.2^{\circ}$ and $22.9^{\circ}$ corresponding to 101 and 002 diffraction planes, respectively. Miller indices were used to label the peaks. Segal crystallinity index was estimated in two steps. In the first step, the subtraction of the background signal was carried out and then height ratio is considered between crystalline peak intensity and total intensity. The high degree of crystallinity was achieved with a more regular chain of finished cotton fabric and larger crystalline area. Figure 6 show the diffractogram for untreated cotton fabric and cotton fabric treated with maleic acid and acrylic acid. No considerable difference was noticed between all spectrums. Finished fabric treated with maleic acid has high crystallinity index due to the presence of two carboxyl acid groups that will form a more regular chain and better water and oil repellency as compared to acrylic acid (table 5).
CRYSTALLINITY INDEX OF UNTREATED COTTON FABRIC AND COTTON FABRIC TREATED WITH BEST RECIPES

\begin{tabular}{|l|c|}
\hline \multicolumn{1}{|c|}{ Sample } & $\begin{array}{c}\text { Crystallinity } \\
\text { Index (\%) }\end{array}$ \\
\hline A1(Control fabric) & 60 \\
\hline $\mathrm{E} 6(\mathrm{SA}+\mathrm{MA}+\mathrm{SHP}+\mathrm{TEA}+\mathrm{IPA})$ & 82 \\
\hline $\mathrm{E}$ ( $\left(\mathrm{SA}+\mathrm{MA}+\mathrm{SHP}+\mathrm{TEA}+\mathrm{IPA}+\mathrm{H}_{2} \mathrm{O}\right)$ & 76 \\
\hline $\mathrm{E} 8(\mathrm{SA}+\mathrm{AA}+\mathrm{SHP}+\mathrm{TEA}+\mathrm{IPA})$ & 78 \\
\hline $\mathrm{E} 9\left(\left(\mathrm{SA}+\mathrm{AA}+\mathrm{SHP}+\mathrm{TEA}+\mathrm{IPA}+\mathrm{H}_{2} \mathrm{O}\right)\right.$ & 75 \\
\hline
\end{tabular}

\section{SEM analysis}

The surface morphology of raw cotton, stearic acidmaleic acid-cotton and stearic acid-acrylic acid-cotton samples were studied by scanning electron microscope analysis. Figure 7 present that untreated cotton fabric surface has no coating and it was plain and smooth. However, the newly synthesized finishes E6 and E8 coating can be clearly observed on the surface of cotton fabric.

\section{EDX analysis}

Commercial recipe of $\mathrm{A} 2$, a $\mathrm{C} 6$ based fluorocarbon indicates the fluorine peak at an energy level of 0.677 $\mathrm{KeV}$ showing counts of 91 . EDX spectrum of samples A1, A15, A7, A9, E6, E7, E8 and E9 exhibited no peak for fluorine showing that control fabric and newly synthesized recipes were free of fluorinated compounds. Highest counts of carbon 669 and oxygen 550 elements can be observed in E6 having maleic acid diluted with isopropyl alcohol due to the presence of more carboxyl groups. Figure 8 showed the EDX spectrum of control fabric compared with cotton fabric coated with newly synthesized fluorinefree recipes.

\section{Contact angle}

Since the cotton fabric is hydrophilic in nature, therefore, water droplet placed on it is spread immediately as shown in figure 9, a. Modified cotton fabric with stearic acid showed contact angle of $101^{\circ}$, as stearic acid (A15) lowers the surface energy of treated cotton fabric but the coating was non-durable.
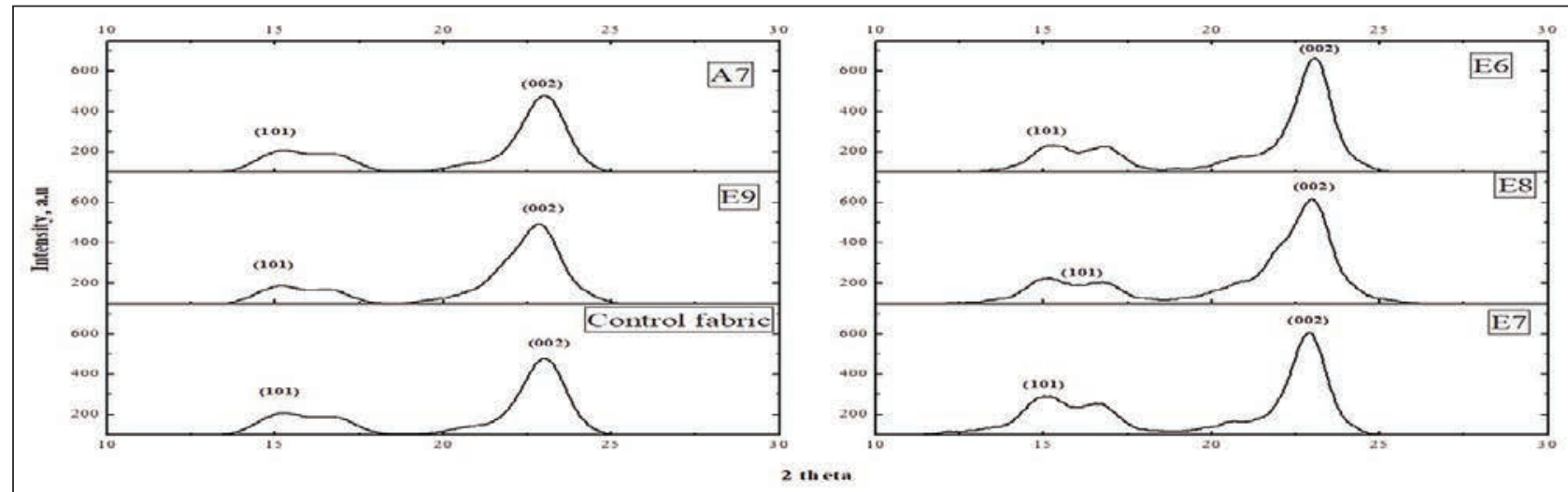

Fig. 6. XRD spectrum for control cotton fabric and modified cotton fabric with maleic acid and acrylic acid 


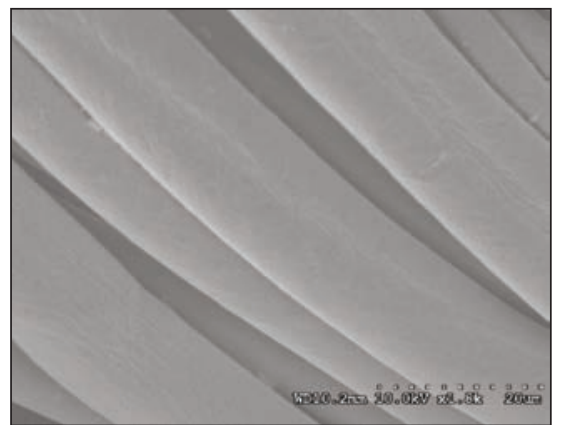

a

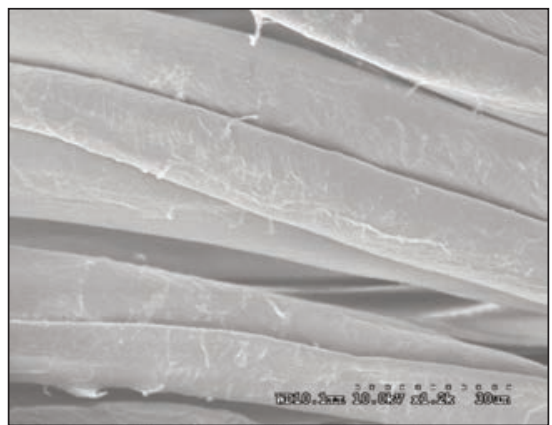

$\boldsymbol{b}$

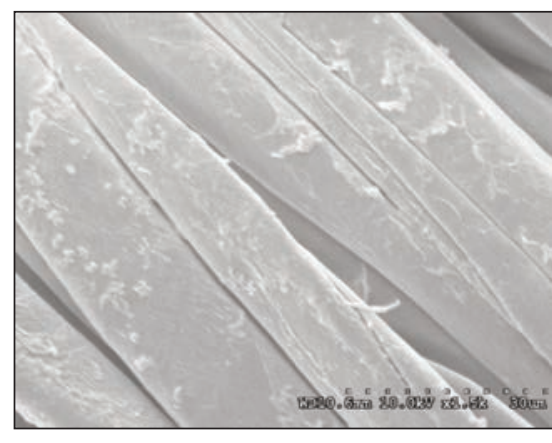

$\boldsymbol{C}$

Fig. 7. SEM analysis of: $a$ - control fabric; $b$ - coated fabric with E8; $c$ - coated with E6 recipes
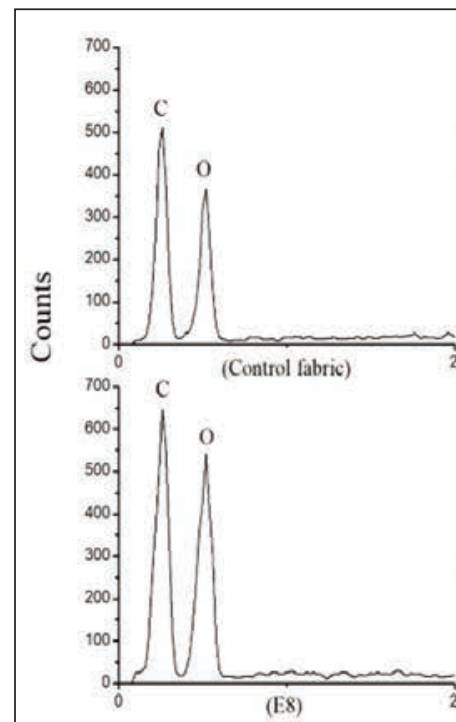

$\mathrm{KeV}$
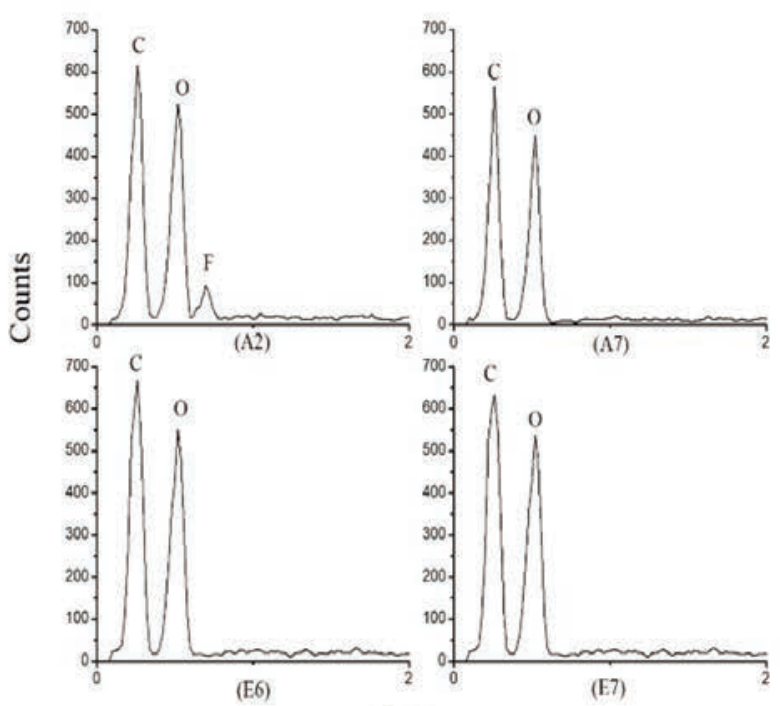

$\mathrm{KeV}$

Fig. 8. EDX spectrum for control cotton fabric and modified cotton fabric with maleic acid and acrylic acid

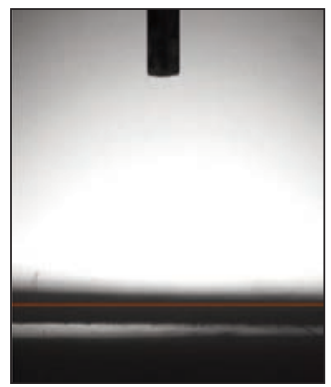

a

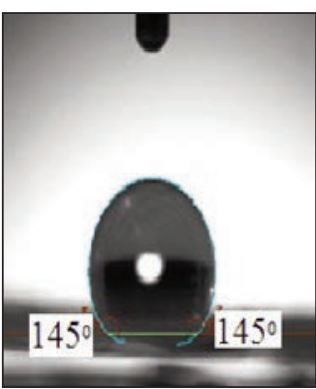

b

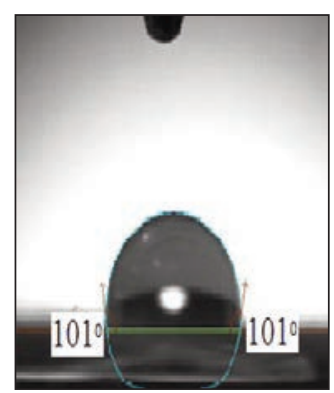

c

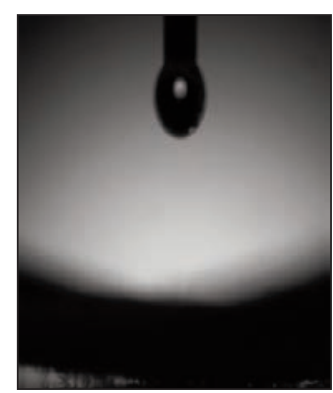

d e

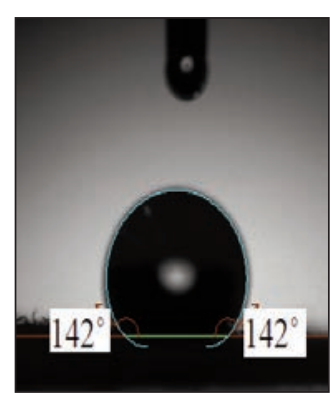

f

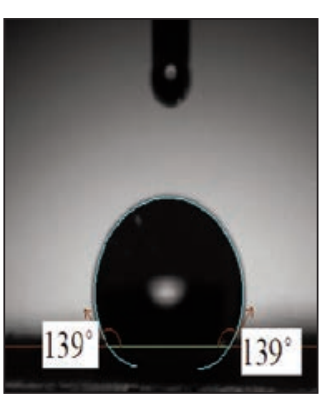

g

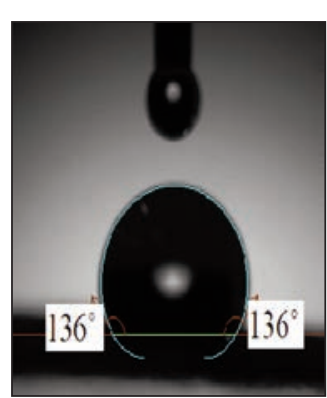

$\boldsymbol{h}$

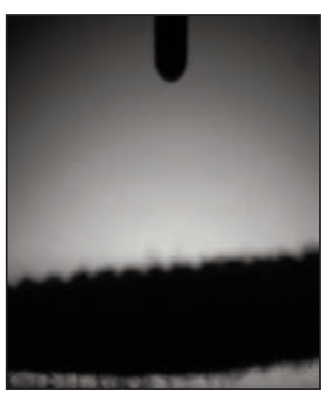

Fig. 9. Contact angles of: $a$ - control fabric; $b-\mathrm{A} 2$ (bench mark); $c-\mathrm{A} 15$ (stearic acid); $d-\mathrm{A} 7$ (maleic acid); $e-\mathrm{A} 9$ (Acryic acid); $f-\mathrm{E} 6 ; g-\mathrm{E} 7 ; h-\mathrm{E} 8 ; i-\mathrm{E} 9$ 
Crosslinkers such as maleic acid (A7) and acrylic acid (A9) showed $0^{\circ}$ contact angle when applied alone on cotton fabric. Sample E6, E7 showed contact angle $142^{\circ}$ and $139^{\circ}$ respectively due to a combination of stearic acid with maleic acid.

Incorporation of cross-linker such as maleic acid with stearic acid increases washing durability of the coating as well as contact angle as shown in table 4. Polymerization of acrylic acid with stearic acid (E8, E9) also improves washing durability of coating and contact angle. However, better and comparable results with benchmark having a contact angle of $145^{\circ}$ were obtained with maleic acid due to the presence of two carboxyl groups. The contact angle of sample E8 and E9 was $136^{\circ}$ and $134^{\circ}$ respectively.

\section{Antimicrobial potential}

Table 6 shows the antibacterial activity of different sample again $E$. coli and $S$. aureus. Raw cotton showed no antibacterial resistance, however, cotton fabric modified with maleic acid and acrylic acid exhibited antibacterial performances. Sample E6 exhibit better antimicrobial properties against grampositive and gram-negative bacteria as compared to E8 due to the presence of two carboxylic acid groups.

Table 6

INHIBITION ZONE OF SAMPLE E6 AND E8 FOR E. COLI AND S. AUREUS BACTERIA

\begin{tabular}{|l|c|c|}
\hline \multirow{2}{*}{ Samples } & \multicolumn{2}{|c|}{ Inhibition zone $(\mathbf{c m})$} \\
\cline { 2 - 3 } & E. coli & S. aureus \\
\hline A1 (control fabric) & 0 & 0 \\
\hline E6 (SA+MA+IPA) & 0.23 & 0.18 \\
\hline E8 (SA+AA+IPA) & 0.17 & 0.16 \\
\hline
\end{tabular}

\section{CONCLUSIONS}

The presented cross-linkers maleic acid and acrylic acid along with stearic acid yielded a successful synthesis of fluorine and formaldehyde-free oil and water repellent for cotton fabric. The newly polymerized recipes application onto the cotton fabric lead to improved crease-resistance, antimicrobial properties, soil release properties, contact angle and oil and water repellency up to 20 washes. Polymerization conditions such as time, temperature and dosage of monomer were optimized. Best results were achieved when $25 \%$ of stearic acid was polymerized with $7 \%$ of maleic acid in the presence of catalyst SHP and enhancer TEA. Combination of stearic acid with maleic acid yielded water repellency rating of 4 and oil repellency rating of 1 before any wash and it attained a value of 3 and 1 respectively after 20 washes. Stearic acid with acrylic acid attained water and oil repellency rating of 4 and 1 prior to any wash, however after 20 washes both of these ratings reduced to 2 and zero respectively. The contact angle of modified cotton samples E6 and E8 was increased to $142^{\circ}$ and $136^{\circ}$ respectively due to a combination of stearic acid with maleic acid and acrylic acid respectively. Ester bond formation was confirmed by FTIR analysis. EDX analysis confirmed the absence of fluorine in the newly synthesized recipes. SEM affirms the coating of newly developed polymer onto the cotton fabric. Therefore, newly developed and optimized recipes can give a good alternative to the current toxic fluorine and formaldehyde-based oil and water repellents.

\section{ACKNOWLEDGEMENTS}

Authors are thankful to UET Lahore for funding this research project (No. ORIC/100-ASRB/1990).

\section{REFERENCES}

[1] Qutab, H.G., Mohsin, M., Ramzan, N., Ahmad, S.W., Mitran, E.C., Performance enhancement of diammonium hydrogen phosphate as halogen and formaldehyde free sustainable fire retardant, In: Industria Textila, 2019, 70, 4, 366-373, http://doi.org/10.35530/IT.070.04.1606

[2] Naeem, J., Mazari, A., Akcagun, E., Havelka, A., Kus, Z., Analysis of thermal properties, water vapour resistance and radiant heat transmission through different combinations of firefighter protective clothing, In: Industria Textila, 2018, 69, 6, 458-465, http://doi.org/10.35530/IT.069.06.1463

[3] Zhang, M., Wang, C., Wang, S., Li, J., Fabrication of superhydrophobic cotton textiles for water-oil separation based on the drop-coating route, In: Carbohydrate Polymer, 2013, 97, 1, 59-64

[4] Khanh, V.T.H., Huong, N.T., Influence of crosslinking agent on the effectiveness of flame retardant treatment for cotton fabric, In: Industria Textila, 2019, 70, 5, 413-420, http://doi.org/10.35530/lT.070.05.1610

[5] Faheem, S., Baheti, V., Tunak, M., Wiener, J., Militky, J., Comparative performance of flame retardancy, physiological comfort, and durability of cotton textiles treated with alkaline and acidic casein suspension, In: Journal of Industrial Textile, 2017, 48, 6, 969-991

[6] Stan, M.S., Nica, I.C., Popa, M., Chifiriuc, C.M., Iordache, O., Iuliana Dumitrescu, I., Diamandescu, L., Dinischiotu, A., Reduced graphene oxide/TiO2 nanocomposites coating of cotton fabrics with antibacterial and self-cleaning properties, In: Journal of Industrial Textile, 2019, 49, 3, 277-293

[7] Tonkova, E.V., Staneva, D., Medel, S., Bosch, P., Grozdanov, P., Nikolova, I., Grabchev, I., Antimicrobial, Antibiofilm and Cytotoxicity Activity of a New Acridine Hyperbranched Polymer in Solution and on Cotton Fabric, In: Fibers and Polymers, 2019, 20, 1, 19-24

[8] Akçali, K., Bulut, M.O., A new finishing process of cotton fabric, In: Industria Textila, 2019, 70, 2, 101-110, http://doi.org/10.35530/IT.070.02.1513

[9] Chauhan, P., Kumar, A., Bhushan, B., Self-cleaning, Stain-resistant and Anti-bacterial Superhydrophobic Cotton Fabric Prepared by Simple Immersion Technique, In: Journal of Colloid and Interface Science, 2019, 535, 66-74

[10] Aileni, R.M., Chiriac, L., Subtirica, A., Albici, S., Dinca, L.C., Aspects of the hydrophobic effect sustainability obtained in plasma for cotton fabrics, In: Industria Textila, 2019, 70, 3, 223-228, http://doi.org/10.35530/ IT.070.03.1475 
[11] Kasapgil, E., Anac, I., Erbi, H.Y., Transparent, Fluorine-Free, Heat-Resistant, Water Repellent Coating by Infusing Slippery Silicone Oil on Polysiloxane Nanofilament Layers prepared by Gas Phase Reaction of $n$ Propyltrichlorosilane and Methyltrichlorosilane, In: Colloids and Surfaces A: Physicochemical and Engineering Aspects, 2019, 560, 223-232

[12] Fahmy, H.M., Amr, A., Aly, A.A., Sayed, S.M., Synthesis of castor oil/2, 4-toluene diisocyanate adducts to impart water repellency and antibacterial properties for cotton/polyester fabric, In: Journal of Coatings Technology and Research, 2019, 16, 1, 31-39

[13] Abo-Shosha, M.H., El-Hilw, Z.H., Aly, A.A., Amr, A., Nagdy, Al Said, I.El., Paraffin wax emulsion as water repellent for cotton/polyester blended fabric, In: Journal of Industrial Textiles, 2008, 37, 4, 315-325

[14] Rahman Bhuiyan, M.A., Wang, L., Shaid, A., Shanks, R.A., Ding, J., Polyurethane-aerogel incorporated coating on cotton fabric for chemical protection, In: Progress in Organic Coatings, 2019, 131, 100-110

[15] Ma, Y., Zhu, D., Si, Y., Gang, S., Fabricating durable, fluoride-free, water repellency cotton fabrics with CPDMS, In: Journal of Applied Polymer Science, 2018, 135, 25, 46396-46402

[16] ZDHC, 2012, Available at: https://www.roadmaptozero.com/ [Accessed $6^{\text {th }}$ June 2019]

[17] Liu, X., Yang, G., Lipik, V., Permanent Water Repellent Chemical Modification of Cotton Fabric with Reagents Containing Aromatic Rings, In: Fibers and Polymers, 2019, 20, 1, 51-56

[18] Xue, C.H., Jia, S.T., Chen, H.Z., Wang, M., Superhydrophobic cotton fabrics prepared by sol-gel coating of TiO2 and surface Hydrophobization, In: Science and Technology of Advance Materials, 2008, 9, 3, 35001-35006

[19] Xue, C.H., Jia, S.T., Zhang, J., Tian, L.Q., Superhydrophobic surfaces on cotton textiles by a complex coating of silica nanoparticles and Hydrophobization, In: Thin Solid Films 2009, 517, 16, 4593-4598

[20] Richard, E., Lakshmi, R.V., Aruna, S.T., Basu, B.J., A simple cost-effective and eco-friendly wet chemical process for the fabrication of superhydrophobic cotton fabrics, In: Applied Surface Science, 2013, 277, 302-309

[21] Arfaoui, M.A., Dolez, P.I., Dube, M., David, E., Preparation of a hydrophobic recycled jute-based nonwoven using a titanium dioxide/stearic acid coating, In: The Journal of Textile Institute, 2019, 110, 1, 1455313-1455323

[22] Zhang, Y., Wang, X., Wang, C., Zhai, H., Liu, B., Zhao, X., Fang, D., Wei, Y., Facile preparation of flexible and stable superhydrophobic non-woven fabric for efficient oily wastewater treatment, In: Surface and Coatings Technology, 2019, 357, 526-534

[23] Arfaoui, M.A., Dolez, P.I., Dube, M., David, E., Development and characterization of a hydrophobic treatment for jute fibres based on zinc oxide nanoparticles and a fatty acid, In: Applied Surface Science, 2017, 397, 19-29

[24] Mohsin, M., Farooq, U., Ramzan, N., Rasheed, A., Ahmad, S., Ahsan, M., Softener impact on environment friendly low and zero formaldehyde cross-linker performance for cotton, In: Industria Textila, 2014, 65, 134-139

[25] Mohsin, M., Ramzan, N., Qutab, H.G., Ahmad, S.W., Sarwar, N., Synthesis of halogen and formaldehyde free bio based fire retardant for cotton, In: Industria Textila, 2017, 68, 3, 221-225, http://doi.org/10.35530/IT.068.03.1328

[26] Xiaohong, G., Yang, C.Q., FTIR Spectroscopy Study of the Formation of Cyclic Anhydride Intermediates of Polycarboxylic Acids Catalyzed by Sodium Hypophosphite, In: Textile Research Journal, 2000, 70, 64-70

[27] Qi, H., Zhao, C., Qing, F., Yan, K., Sun, G., Antiwrinkle Finishing of Cotton Fabrics with 5-(Carbonyloxy succinic)benzene-1,2,4-tricarboxylic Acid: Comparison with Other Acids, In: $\square$ Industrial \& Engineering Chemistry Research, 2016, 55, 46, 11850-11856

[28] Mohsin, M., Sarwar, N., Ahmad, S., Rasheed, A., Ahmad, F., Afzal A., Zafar S., Maleic acid crosslinking of C-6 fluorocarbon as oil and water repellent finish on cellulosic fabrics, In: Journal of Cleaner Production, 2016, 112, 4, 3525-3530

[29] Tavera-Quiroz, M.J., Diaz, J.J.F., Pinotti, A., Characterization of Methylcellulose Based Hydrogels by Using Citric Acid as a Crosslinking Agent, In: International Journal of Applied Engineering Research, 2018, 13, 17, 13302-13307

[30] Tang, P., Ji, B., Sun, G., Whiteness improvement of citric acid cross-linked cotton fabrics: $\mathrm{H}_{2} \mathrm{O}_{2}$ bleaching under alkaline condition, In: Carbohydrate Polymers, 2016, 147, 139-145

[31] Huang, Z., Zhou, X., Xing, Z., Wang, B., Improving Application Performance of in situ Polymerization and Crosslinking System of Maleic Acid/Itaconic Acid for Cotton Fabric, In: Fibers and Polymers, 2018, 19, 2, 281-288

[32] Udomkichdecha, W., Kittinaovarat, S., Thanasoonthornroek, U., Potiyaraj, P., Likitbanakorn, P., Acrylic and Maleic Acids in Nonformaldehyde Durable Press Finishing of Cotton Fabric, In: Textile Research Journal 2003, 73, 401-406

[33] Mattonai, M., Pawcenis, D., Seppia, S.D., Lojewska, J., Ribechini, E., Effect of ball-milling on crystallinity index, degree of polymerization and thermal stability of cellulose, In: Bioresource Technology, 2018, 270, 270-277

Authors:

\section{SHARIF RABIA ${ }^{1}$, MOHSIN MUHAMMAD ${ }^{2}$, RAMZAN NAVEED ${ }^{3}$,} AHMAD SYED WAQAS ${ }^{1}$, HAJI GHULAM QUTAB ${ }^{1}$

${ }^{1}$ Department of Chemical Engineering, UET Lahore, Faisalabad Campus, Pakistan

${ }^{2}$ Department of Textile Engineering, UET Lahore, Faisalabad Campus, Pakistan

${ }^{3}$ Department of Chemical Engineering, UET Lahore, Main Campus, Pakistan

\section{Corresponding author:}

email: mohsinmalikntu@yahoo.com 